\title{
Genetic structure of the seagrass Posidonia oceanica in the Western Mediterranean: ecological implications
}

\author{
Gabriele Procaccini ${ }^{1, *}$, Randall S. Alberte ${ }^{2}$, Lucia Mazzella $^{1}$ \\ ${ }^{1}$ Laboratorio di Ecologia del Benthos della Stazione Zoologica 'A. Dohrn' di Napoli, I-80077 Ischia, Italy \\ ${ }^{2}$ Biological Science and Technology Program, Office of Naval Research, Arlington, Virginia 22217, USA
}

\begin{abstract}
The seagrass Posidonia oceanica (L.) Delile plays a dominant role in coastal ecosystem dynamics in the Mediterranean Sea. This species reproduces both sexually through germination and asexually through vegetative propagation of subterranean rhizomes. Though flowering and fruiting are common, seedlings rarely succeed. An extensive population of $P$. oceanica on the coast of the Island of Ischia (Gulf of Naples. Italy) was found to be nearly clonal when analysed with 2 DNA fingerprinting techniques, minisatellites and random amplified polymorphic DNA (RAPD); the results show similarity values of 1 and $>0.91$, respectuvely. Furthermore, a comparably high genetic similarity was observed between this population and individuals from another Ischia population and from the coast of Spain. These findings support clonal propagation as the dominant reproductive mode for this species. The presence of limited numbers of genotypes in the Western Mediterranean basin coupled with a very slow rhızome elongation rate and the signufıcant anthropogenic stress on these populations is cause for concern over the long-term ecological stability of this keystone species.
\end{abstract}

KEY WORDS: Clonality · DNA fingerprinting - Minisatellite polymorphism - RAPD - Posidonıa Seagrass

\section{INTRODUCTION}

Marine vascular plants play a multi-functional role in the structure and dynamics of coastal benthic systems in temperate and tropical seas (McRoy \& Helfferich 1977, Larkum et al. 1989). In the Mediterranean Sea, Posidonia oceanica is endemic and forms large and widespread meadows in the littoral zone (Boudouresque et al. 1984). This seagrass constitutes the structural species of a complex ecosystem, characterized by high biodiversity and productivity (Gambi et al. 1992, Mazzella et al. 1992). Long-term natural climate changes and/or anthropogenic modifications have disturbed these systems, resulting in bed erosion and biomass losses throughout the Mediterranean Sea (Mazzella \& Buia 1989, Bellan-Santini et al. 1994).

Posidonia oceanica reproduces sexually by seed production ( 2 to 4 seeds per flowering shoot) and asexu-

·E-mail: gpro@alpha.szn.it ally by vegetative propagation of subterranean rhizomes. The hermaphroditic flowers are organized in spike-like terminal inflorescences, and fruits are large (14 to $21 \mathrm{~mm}$ long) and buoyant, while seeds sink to the sediment (Caye \& Meinesz 1984, Boudouresque \& Thelin 1985). Vegetative reproduction appears to be very important for the physical stability and resilience of meadows, whereas sexual reproduction probably functions in long distance species dispersal and for genetic diversity (Buia \& Mazzella 1991). Previous efforts examining the incidence and significance of sexual reproduction in the establishment and propagation of $P$. oceanica beds were based on in situ studies of reproductive phenology and laboratory observations of seed germination and seedling success. Though flowering of $P$. oceanica is frequent in the Mediterranean basin, in recent years establishment of seedlings under natural conditions has been episodic at best (Caye \& Meinesz 1984, Thelin \& Boudouresque 1985, Buia \& Mazzella 1991, Meinesz et al. 1993). This species is characterised by very slow vegetative growth, with 
estimated rates of orthotropic (vertical) rhizome elongation ranging between 0.4 and $1.1 \mathrm{~cm} \mathrm{yr}^{-1}$ and plagiotropic (horizontal) elongation between 0.4 and $7.4 \mathrm{~cm}$ $\mathrm{yr}^{-1}$ (Boudouresque \& Jeudy de Grissac 1983). The organogenic structure ('matte') formed by horizontal and vertical rhizomes can be greater than $1 \mathrm{~m}$ thick over the underlying sediment and provides a longterm record of the growth and production dynamics of the species. It has been estimated that some populations growing on 'matte' terraces can be several thousands of years old in the Mediterranean (Boudouresque \& Jeudy de Grissac 1983, Mateo et al. in press).

Clonal plants form extensive and long-lived populations that can arise from a single genet. The number of genets, however, is strictly related to the frequence of sexual reproduction. Thus there is a strong interplay between sexual and asexual reproduction in the genetic make-up of natural populations.

The aim here was to (1) evaluate the relative importance of sexual versus vegetative reproduction in Posidonia oceanica genetic composition, (2) establish the level of gene flow within meadows, and (3) begin to assess the gene flow between geographically disjunct populations in the Western Mediterranean. We exploited 2 DNA fingerprinting techniques, minisatellites and random amplified polymorphic DNA (RAPD). The results obtained from the latter analysis were also utilized to compare the dominant reproductive strategies between $P$. oceanica and another Mediterranean seagrass, Cymodocea nodosa (Procaccini \& Mazzella 1996).

Minisatellite analysis can allow researchers to distinguish between genets undetectable using other molecular markers and has been used widely in a variety of studies of animals and terrestrial plants to examine the

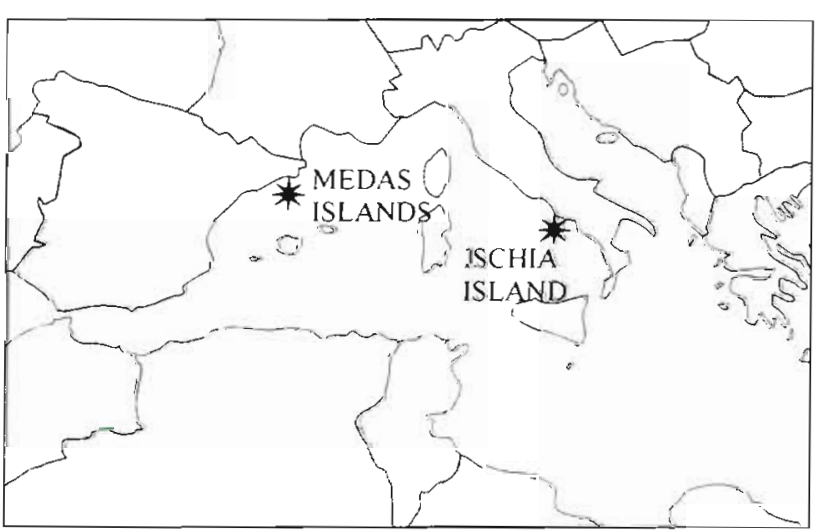

Fig. 1. Maps of the Western Mediterranean basin, the Island of Ischia and the Lacco Ameno meadow, indicating the locations of the 3 Posidonia oceanica populations examined in this study. Distance between the Italian and the Spanish populations is greater than $1000 \mathrm{~km}$. The positions of the 2 transects are shown for Lacco Ameno genetic structure of natural populations (Nybom \& Schaal 1990, Burke et al. 1991, Carvalho et al. 1991, van Pijlen et al. 1991, Baker et al. 1992, Coffroth et al. 1992). More recently, the RAPD technique has become widely used in population genetic studies (Russell et al. 1993, Gustafsson \& Gustafsson 1994, Van Oppen et al. 1994, 1995, Waycott 1995). Few studies to date have applied these molecular technologies to marine vascular plants (Alberte et al. 1994, Coyer et al. 1994, 1995, Waycott 1995, Procaccini \& Mazzella 1996) and this is the first usage for this Mediterranean species. In addition, this is the first study in which the 2 techniques are compared in seagrasses, allowing us to detect variability in different DNA regions (non-coding minisatellite and randomly amplified DNA regions).

\section{MATERIAL AND METHODS}

Posidonia oceanica (L.) Delile shoots were collected from a meadow in Lacco Ameno Bay, Island of Ischia (Gulf of Naples, Italy) (Fig. 1). This meadow is distributed over a depth range of 3 to $33 \mathrm{~m}$ and extends over an area greater than $8 \times 10^{3} \mathrm{~m}^{2}$ (V. Zupo, L. Mazzella, M. C. Buia, M. C. Gambi, M. Lorenti, M. B. Scipione unpubl.) with a shoot density between 163 and 341 shoots $\mathrm{m}^{2}$, depending on depth (Buia et al. 1992). Individual plants were collected at $10 \mathrm{~m}$ intervals along 2 parallel transects separated by $400 \mathrm{~m}$ at 5 and $24 \mathrm{~m}$

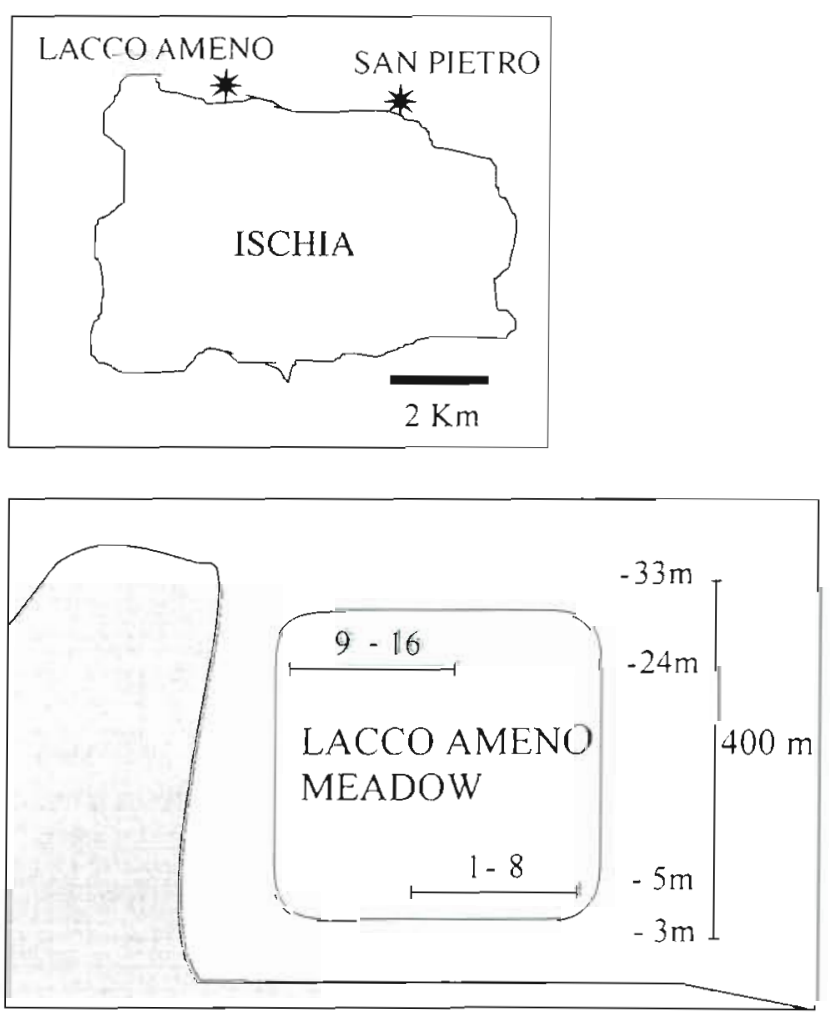


depth (Fig 1). The 2 transects were chosen on the basis of the extensive data base on the occurrence of flowering and fruiting in the population of Lacco Ameno demonstrating the presence of a phase difference between shallow (down to $15 \mathrm{~m}$ ) and deep stands (from 15 to $28 \mathrm{~m}$ ) (Buia \& Mazzella 1991). An equal number of shoots were considered at the 2 different depths and the resulting banding pattern was then compared with 2 other spatially disjunct Mediterranean populations: one $5 \mathrm{~km}$ away at San Pietro, Ischia, and another about $1000 \mathrm{~km}$ away on the Medas Islands, Catalan coast, Spain.

DNA isolation. Leaf tissue (3 to $4 \mathrm{~g}$ fresh weight), cleaned of epiphytes, was ground in liquid $\mathrm{N}_{2}$ and DNA was extracted in $8 \mathrm{ml}$ of $2 \times$ CTAB buffer (Doyle \& Doyle 1987) per $g$ tissue, with the addition of SDS, 2mercaptoethanol, and polyvinylpolypyrrolidone to final concentrations of $0.5 \%(\mathrm{w} / \mathrm{v}), 67 \mathrm{mM}$, and $0.4 \%$ $(w / v)$, respectively. Extracts were incubated for 60 to 90 min at $60^{\circ} \mathrm{C}$ with gentle shaking, extracted twice with an equal volume of chloroform-isoamyl alcohol (24:1) (Sevag) and separated by centrifugation at 3000 $\times g$ for 15 min. DNA was precipitated with 1 vol of cold isopropanol for either $30 \mathrm{~min}$ or overnight at $-20^{\circ} \mathrm{C}$ and nucleic acids were concentrated by centrifugation at $13000 \times \mathrm{g}$ at $4^{\circ} \mathrm{C}$. Nucleic acid pellets were dissolved in $200 \mu \mathrm{HE}(10 \mathrm{mM}$ Tris-HCl, $1 \mathrm{mM}$ EDTA, pH 8.0) and RNase $A$ was added to a final concentration of $10 \mathrm{\mu g} \mathrm{ml} \mathrm{m}^{-1}$, incubated for $60 \mathrm{~min}$ at $37^{\circ} \mathrm{C}$, washed 1 time with Phenol/Sevag, 1 or 2 times with Sevag, precipitated with $2.5 \mathrm{vol}$ of absolute ethanol $\left(-20^{\circ} \mathrm{C}\right.$ overnight) and dissoved in TE. The method yielded 50 to $100 \mathrm{\mu g}$ of DNA per $\mathrm{g}$ fresh tissue. Further purification of the DNA using CsCl-gradient ultracentrifugation was found to be unnecessary.

Minisatellite. Genomic DNA (6 $\mu \mathrm{g})$ was digested with 40 units of 6 restriction enzymes in separate reactions (AJuI, DdeI, DraI, EcoRI, HindIII, Rsal) according to the manufacturer's protocol (New England Biolabs). The restriction fragments were size-fractionated in $0.8 \%$ agarose gels at $50 \mathrm{~V}$ for $24 \mathrm{~h}$ in $45 \mathrm{mM}$ Trisborate, 1 mM EDTA buffer, vacuum-transferred to nylon membranes (HyBond-N, Amersham) by vacuum blotting (BioRad) and cross-linked by UV. Three probes were used, termed M13, and Jeffreys' probes 33.15 and 33.6 (Jeffreys et al. 1985). For the M13 probe, membranes were prehybridized for $2 \mathrm{~h}$ at $37^{\circ} \mathrm{C}$ in prehybridization buffer $[6 \times \mathrm{SSC}(0.9 \mathrm{M} \mathrm{NaCl}$, $0.09 \mathrm{M}$ sodium citrate dehydrate, $\mathrm{pH} 7.0$ ), 1× Denhardt's reagent $10.02 \%$ bovine serum albumin, $0.02 \%$ Ficoll, $0.02 \%$ polyvinylpyrrolidone), 1\% SDSI and transferred to hybridization buffer containing a digoxygenin-conjugated dUTP-labeled probe consisting of a $771 \mathrm{bp}$ fragment of M13mp18. The probe was labeled using the Polymease Chain Reaction (PCR)
(Coyer et al. 1994). Hybridization was accomplished by incubating the membrane for $16 \mathrm{~h}$ at $37^{\circ} \mathrm{C}$. Membranes were washed twice for $10 \mathrm{~min}$ at $37^{\circ} \mathrm{C}$ and once for $15 \mathrm{~min}$ at $50^{\circ} \mathrm{C}$ in $0.5 \times \mathrm{SSC} / 0.1 \% \mathrm{SDS}$. For Jeffreys' probes 33.15 and 33.6 (Jeffreys et al. 1985), membranes were prehybridized for $1 \mathrm{~h}$ at room temperature in blocking buffer [1x phosphate buffer $10.058 \mathrm{M}$ $\mathrm{Na}_{2} \mathrm{HPO}_{4}, 0.017 \mathrm{M} \mathrm{NaH} \mathrm{PO}_{4} \cdot \mathrm{H}_{2} \mathrm{O}, \mathrm{pH} 7.4,0.068 \mathrm{M}$ $\mathrm{NaCl}$ ); $0.2 \%$ Hammarstan grade casein, $0.1 \%$ Tween20) and transferred to hybridization buffer $15 \times$ SSC, $\mathrm{pH} 7.0,1 \%$ SDS, $0.5 \%$ BSA, $0.5 \%$ polyvinylpyrrolidone) along with the alkaline phosphatase-conjugated oligonucleotide probes corresponding to the core probe of the human minisatellites 33.15 and 33.6 (Jeffreys et al. 1985) Hybridization was accomplished by incubating the membrane for $30 \mathrm{~min}$ at $50^{\circ} \mathrm{C}$. Membranes were then washed 3 times in $1 \times \mathrm{SSC} / 1.0 \% \mathrm{SDS}$ at $50^{\circ} \mathrm{C}$ for $10 \mathrm{~min}$ and once in $1 \times \mathrm{SSC}$ at room temperature for $10 \mathrm{~min}$. Chemiluminescent detection of the hybridized probe was accomplished by incubating the membranes with LumiPhos (Boehringer Mannheim Biochemicals) diluted 1:8 and exposing them to Kodak X-AR-5 film. Bands were manually scored and molecular size was calculated by comparison with the known molecular size marker. Lambda-HindIII marker does not hybridize with 33.15 and 33.6 Jeffreys' probes and the relative position of bands was calculated by agarose gel photographs. Comparisons among gels were accomplished by running the same individual in several gels. Band comparison methods, suggested by Coyer et al. (1994), were not necessary.

RAPD-PCR. PCR was performed in a total volume of $100 \mathrm{\mu l}$ [final concentrations were $50 \mathrm{mM} \mathrm{KCl}$, $10 \mathrm{mM}$ Tris- $\mathrm{HCl} \mathrm{pH} 9.0,1 \%(\mathrm{w} / \mathrm{v})$ Triton X-100, $200 \mu \mathrm{M}$ of each nucleotide, $2 \mathrm{mM} \mathrm{MgCl}, 20 \mathrm{pmol}$ of a single 10-base primer, 2 units of Taq DNA polymerase (Perkin Elmer Cetus)] in the presence of $100 \mathrm{ng}$ of template. Amplifications were carried out for 45 cycles of $1 \mathrm{~min}$ at $94^{\circ} \mathrm{C}, 1 \mathrm{~min}$ at $36^{\circ} \mathrm{C}$, and 2 min at $72^{\circ} \mathrm{C}$. The PCR products were precipitated with EtOH, resuspended in $10 \mu \mathrm{TE}$ (Tris-EDTA) and then run on $1.4 \%$ agarose gel, ethidium bromide stained and UV visualised. Amplifications were replicated 3 times for each sample and only consistent bands were taken into consideration. Band matching was manually scored. All possible pairwise comparisons among individuals were performed using SIM, an MS-DOS-based program, for DNA fingerprinting (Alberte et al. 1994).

Average genetic similarity was calculated, both in DNA fingerprinting and in RAPD-PCR, using the equation of Lynch $\left[S=2 m_{i j} /\left(n_{1}+n_{1}\right)\right.$, where $m_{i j}$ is the number of matching bands between a pair of individuals $i$ and $j$, and $n$ is the number of bands possessed by individuals $j$ and $j$ ] (Lynch 1990). 


\section{RESULTS}

Six different restriction enzymes and 3 different probes were used in the DNA fingerprinting analysis (Table 1). An average of 21 bands, ranging from 1.3 to $12.5 \mathrm{~kb}$, were detected and scored for each of 18 individual plants (Table 1). The restriction patterns of the Lacco Ameno population were compared with individuals from the 2 spatially disjunct populations at San Pietro, Ischia, and at the Medas Islands, Spain. Complete identity was observed among the 16 individuals from the Lacco Ameno population (Table 1, Figs. 2a, b \& 3). The DNA fingerprint from the individual from the San Pietro population was also identical to those from the Lacco Ameno meadow. A very high similarity $\left(S_{\mathrm{b}}=\right.$ 0.97 to 0.98 ) arising from a single band difference in 2 enzyme/probe combinations (Dra I/M13 and Rsal/M13) was found between the individuals from the Catalan coast and the Lacco Ameno population (Table 1. Fig $2 a, b)$. Since high or complete similarity was obtained using so high a number of enzymes and probes ( 6 different restriction enzymes and 3 different probes) and since the likelihood of genetic identity between 2 non-clonal individuals, when determined by DNA. fingerprinting, is less than 1 in $70 \times 10^{9}$ (Kirby 1990), we conclude that the Italian populations are clonal and that Posidonia oceanica in the Western Mediterranean is essentially clonal.

RAPD analysis, which samples different parts of the genome as compared to multilocus DNA fingerprint techniques (Hadrys et al. 1992, Rafalski \& Tingey 1993, Avise 1994), further verified the unprecedented clonality of the Posidonia oceanica seagrass population. Amplification products were generated from 22 ten-base primers. Eleven of these generated consistent banding patterns. A total of 68 RAPD products, ranging in molecular size from 0.3 to $2.7 \mathrm{~kb}$, were identified (Table 2, Fig. 4), of which only one was polymorphic $(1.47 \%)$. The average number of bands per primer was 61 . Greater than $99 \%$ similarity was obtained among 16 individuals from the Lacco Ameno population and between these individuals and the ones from the San Pietro and Spain (Table 2). These data confirm the conclusions from the minisatellite analyses.

\section{DISCUSSION}

In our analysis of genetic variability of Posidonia oceanica populations 2 different DNA fingerprinting technologies were applied, minisatellite and RAPDPCR. Minisatellite DNA fingerprinting reveals variability in the number of tandem repeats of highly variable regions of non-coding DNA, while RAPD-PCR reveals the variability of randomly amplified regions of DNA. These 2 approaches used in combination should ensure the greatest likelihood of detecting genetic differences between individuals simply because a large spectrum of the genome is addressed Furthermore, the minisatellite analysis exploited several restriction enzymes and several probes while a large number of primers was used in the RAPD analyses to further
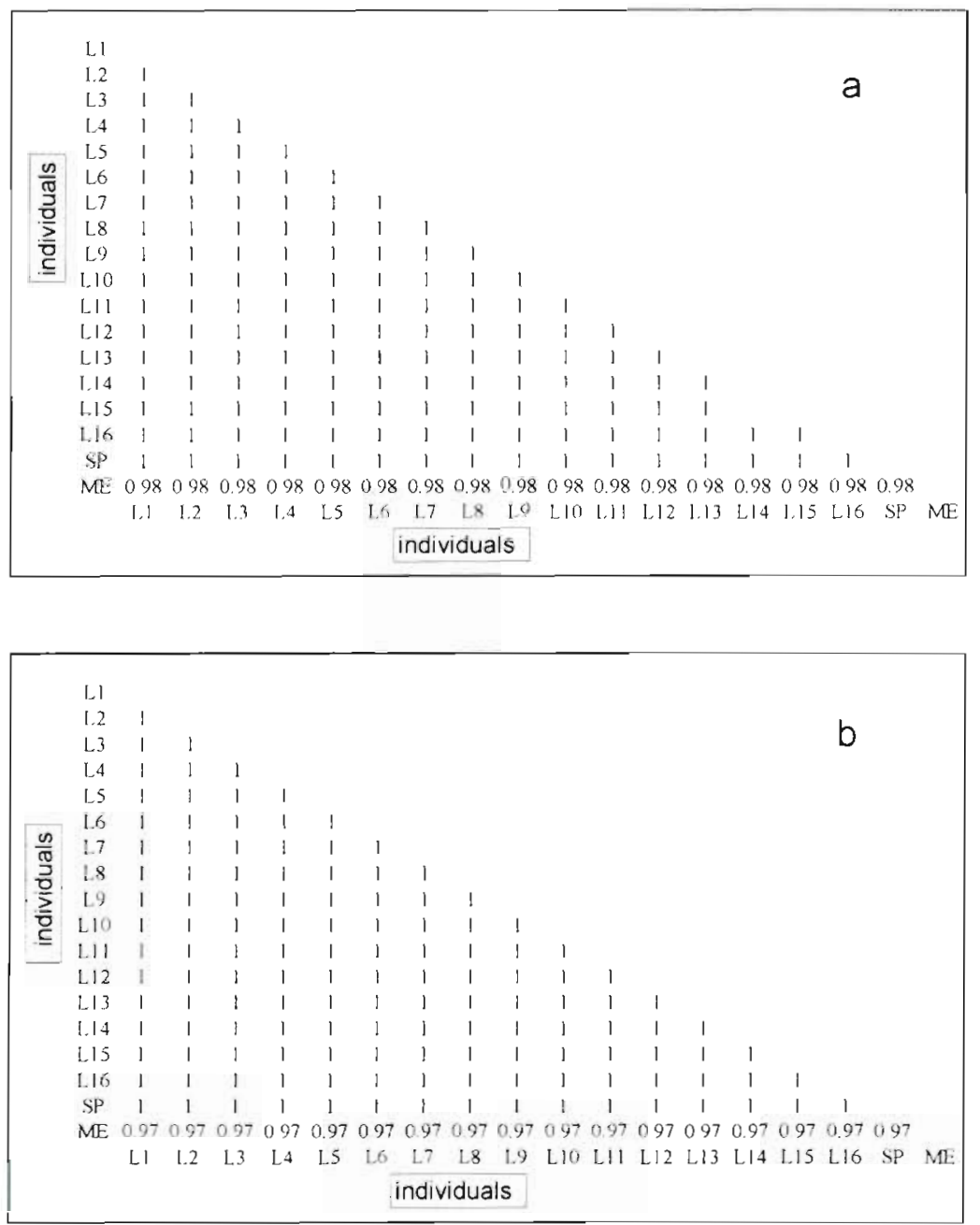

Fig. 2. Minisatellite simılarity matrix for the 2 enzyme/probe combinations Polymorphism of only 1 band is revealed between the Italian and the Spanish populations. (a) Restriction enzyme Dral, probe M13; (b) Restriction enzyme Rsal, probe M13. L1 to L16: Lacco Ameno meadow; SP: San Pietro meadow; ME: Medas Islands meadow 
Table 1. DNA fingerprinting analysis of Posidonia oceanica. Total number of individuals ( $N$ ), number of bands $(n)$, band molecular size range, similarity within $\left(S_{w}\right)$ and similarity between $\left(S_{b}\right)$ populations for each restriction enzyme/probe combination are shown. Bands were scored as matching when the calculated molecular sizes fell within 3 standard deviations of each other Average genetic similarity was calculated using the equation of Lynch (1990). The 16 individuals from the Lacco Ameno Bay population (1schia, Gulf of Naples, Italy) were compared with 1 individual from the San Pietro population (Ischia, Gulf of Naples, Italy) and 1 individual from the Medas Island population (Catalan Coast, Spain). The numbers in parenthesis indicate the only differences between the Italian and the Spanish populations

\begin{tabular}{|c|c|c|c|c|c|}
\hline $\begin{array}{l}\text { Restr. enzyme } \\
\text { Probe }\end{array}$ & $N$ & $\mathrm{n}$ & $\begin{array}{l}\text { Molecular } \\
\text { size }(\mathrm{kb})\end{array}$ & $S_{\mathrm{w}}$ & $S_{\mathrm{b}}$ \\
\hline \multicolumn{6}{|l|}{ AluI } \\
\hline M13 & 18 & 15 & $3.0-1.5$ & 1 & 1 \\
\hline 33.15 & 18 & 18 & $3.5-1.5$ & 1 & 1 \\
\hline 33.6 & 18 & 16 & $3.5-1.5$ & 1 & 1 \\
\hline \multicolumn{6}{|l|}{ Dde I } \\
\hline M13 & 18 & 18 & $4.5-1.8$ & 1 & 1 \\
\hline 33.15 & 18 & 28 & $6.0-1.3$ & 1 & 1 \\
\hline 33.6 & 18 & 15 & $5.2-2.0$ & 1 & 1 \\
\hline \multicolumn{6}{|l|}{ Dra I } \\
\hline M13 & 18 & $27(26)$ & $12.5-1.8$ & 1 & 0.98 \\
\hline 33.15 & 18 & 25 & $9.0-1.5$ & 1 & 1 \\
\hline 33.6 & 18 & 26 & $9.0-1.5$ & 1 & 1 \\
\hline \multicolumn{6}{|l|}{ EcoR I } \\
\hline M13 & 18 & 17 & $4.5-1.8$ & 1 & 1 \\
\hline 33.15 & 18 & 21 & $10.5-1.5$ & 1 & 1 \\
\hline 33.6 & 18 & 28 & $10.5-1.8$ & 1 & 1 \\
\hline \multicolumn{6}{|l|}{ Hind III } \\
\hline M13 & 18 & 19 & $5.5-1.5$ & 1 & 1 \\
\hline 33.15 & 18 & 22 & $10.5-1.8$ & 1 & 1 \\
\hline 33.6 & 18 & 25 & $10.5-1.6$ & 1 & 1 \\
\hline \multicolumn{6}{|l|}{ Rsa I } \\
\hline$M 13$ & 18 & $20(19)$ & $5.0-2.0$ & 1 & 0.97 \\
\hline 33.15 & 18 & 17 & $5.0-2.0$ & 1 & 1 \\
\hline 33.6 & 18 & 20 & $5.0-2.0$ & 1 & 1. \\
\hline
\end{tabular}

enhance our ability to detect genetic differentiation. The 2 approaches gave almost identical results. The 2 analyses not only revealed unambiguously that the $P$. oceanica populations in the Bay of Naples are clonal, but that the populations of this species in the Western Mediterranean are composed of a low number of genets.

Previous application of DNA fingerprinting techniques to the seagrasses Posidonia australis from Australia and Zostera marina from California revealed low population genetic similarity. Alberte et al. (1994) showed, using minisatellite analysis, (1) low within $\left(S_{\mathrm{w}}=0.44\right.$ to 0.68$)$ and between $\left(S_{\mathrm{b}}=0.47\right.$ to 0.51$)$ population similarities in geographically disjunct populations of Z. marina, (2) restricted gene flow between populations in close proximity, and (3) the absence of any clones among a total of 66 individuals. The RAPD-
EcoRI Hind III

L1 L12 L3 L14

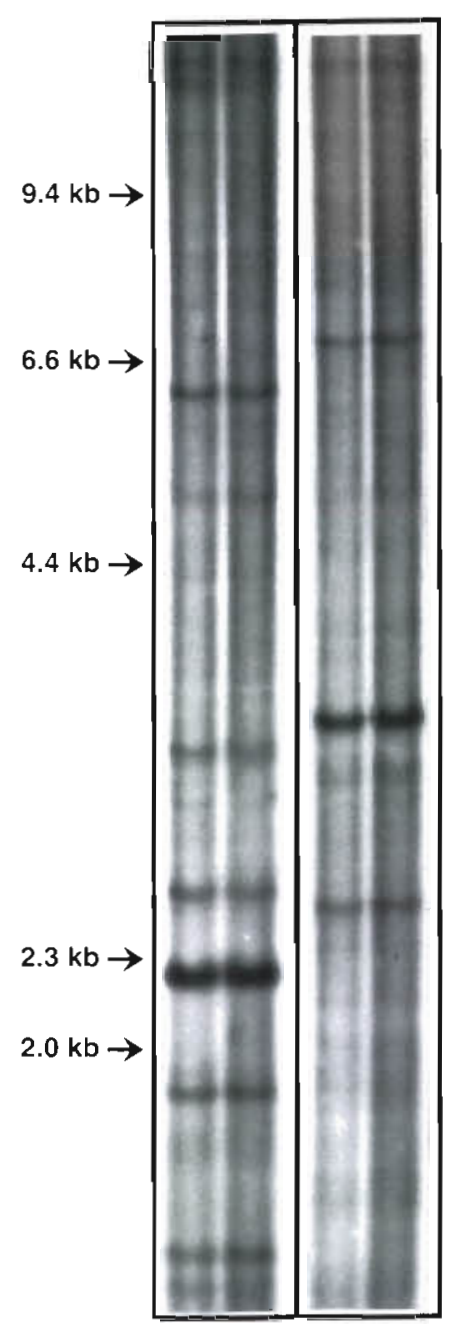

EcoRI
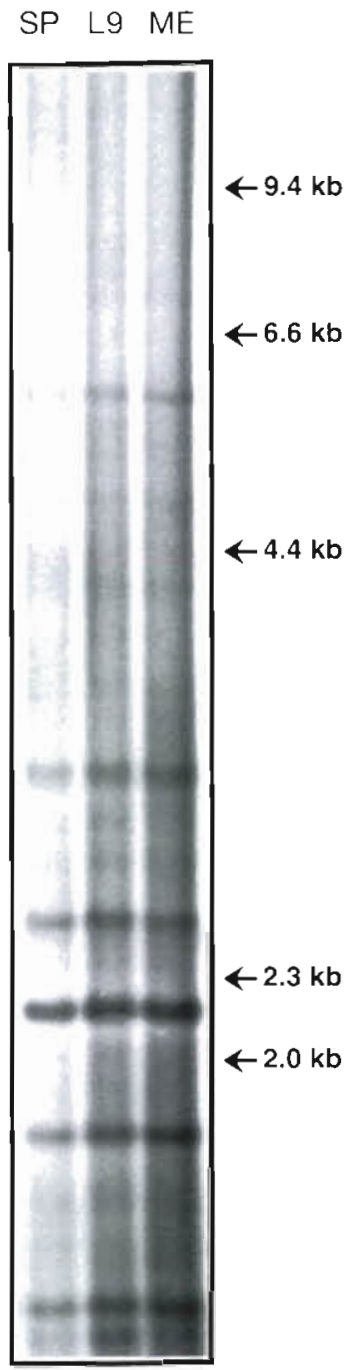

Fig. 3. Representative minisatellite fingerprints of individual plants of Posidonia oceanica from 3 populations. L: Lacco Ameno; SP: San Pietro; and ME: Medas Islands. Each sample contains $6 \mu \mathrm{l}$ of genomic DNA digested with EcoR I and Hind III and hybridized with the Jeffreys' probe 33.15. Samples L 1 and L.3 are from $5 \mathrm{~m}$ depth and samples L9, L12 and L14 are from $24 \mathrm{~m}$ depth

PCR technique identified high polymorphism among individuals in a small $P$. australis population in western Australia (Waycott 1995), and more recently, a short report indicated some polymorphism in P. oceanica along the Thyrrenean coast of Italy (Franconi et al. 1995).

From our analysis, the genetic structure of Posidonia oceanica in the Western Mediterranean appears to be quite different from that observed in these previous studies on seagrasses. Based on 'matte' thickness $(90 \mathrm{~cm})$ and carbon dating, the $P$. oceanica population in Lacco Ameno is more than 2000 yr old (Mateo et al. 
Table 2. The number of RAPD amplification products generated with $1 \mathrm{I}$ primers that gave distinct and scorable amplification products for Posidonia oceanica. Amplifications were replicated 3 times for each sample and only consistent bands were taken into consideration. Denomination of the OPC primers was as suggested by OPERON (Operon Technologies, Inc.). N: total number of individuals, 16 from Lacco Ameno, 1 from San Pietro and 1 from Medas Islands; n: number of $\operatorname{loci}_{i} S_{w}$ : similarity within populations $S_{i} S_{b}$ : similarity between populations. The polymorphic band is from a Lacco Ameno individual. For primer sequences see Procaccini \& Mazzella (1996). Band matching was manually scored and genetic similarity was calculated as for minisatellites. All possible pairwise comparisons among individuals were performed using SIM, an MS-DOS-based program, for DNA fingerprinting (Alberte et al. 1994)

\begin{tabular}{|lccccc|}
\hline Primer & $\mathrm{N}$ & $\mathrm{n}$ & $\begin{array}{c}\text { No. of polymorphic } \\
\text { amplification products }\end{array}$ & $S_{\mathrm{w}}$ & $S_{\mathrm{b}}$ \\
\hline OPC-01 & 18 & 7 & 0 & 1 & 1 \\
OPC-02 & 18 & 6 & 0 & 1 & 1 \\
OPC-05 & 18 & 9 & 0 & 1 & 1 \\
OPC-06 & 18 & 5 & 0 & 1 & 1 \\
OPC-07 & 18 & 6 & 1 & 0.91 & 1 \\
OPC-08 & 18 & 5 & 0 & 1 & 1 \\
OPC-10 & 18 & 5 & 0 & 1 & 1 \\
OPC-11 & 18 & 6 & 0 & 1 & 1 \\
OPC-12 & 18 & 5 & 0 & 1 & 1 \\
DN-4 & 18 & 6 & 0 & 1 & 1 \\
DN-5 & 18 & 8 & 1 & 1 & 1 \\
Totals & \multicolumn{7}{c}{ \% polymorphism: 1.47; mean similarity: 1.0} & \\
\multicolumn{7}{c}{ \% } & 0 & & \\
\hline
\end{tabular}

in press). Why does such an old population possess such a high degree of genetic similarity among individuals? There are at least 2 possibilities. Either clonal or asexual propagation is the predominant mode of reproduction, or $P$. oceanica is almost exclusively homozygous at the genetic level. Since flowering in the Lacco Ameno meadow has been observed to occur on a regular annual basis for the last $10 \mathrm{yr}$ but not a single seedling has been observed (Buia \& Mazzella 1991, authors' unpubl. obs.), we believe that in recent history clonal propagation has dominated reproduction and historically most likely accounts for the genetic structure of the meadow (Procaccini \& Mazzella 1996), as already hypothesized by Caye \& Meinesz (1992).

The population is characterized by a sharp discontinuity, revealed in physical parameters (presence of thermocline), in growth patterns, in timing of flowering and fruiting, in the presence/absence of the 'matte' and in the structure of the meadow that shows a different variability in shoot density along a depth transect (Buia \& Mazzella 1991, Buia et al. 1992, Mazzella et al. 1984, Zupo et al. unpubl.). In spite of these variable features, our analysis showed that the population is genetically homogeneous in the 2 stands (at 5 and $24 \mathrm{~m}$ depth) which are located above and below the discontinuity level. The fact that only one or a very limited number of clones contribute to the genetic structure of this population implies that fruits are exported from

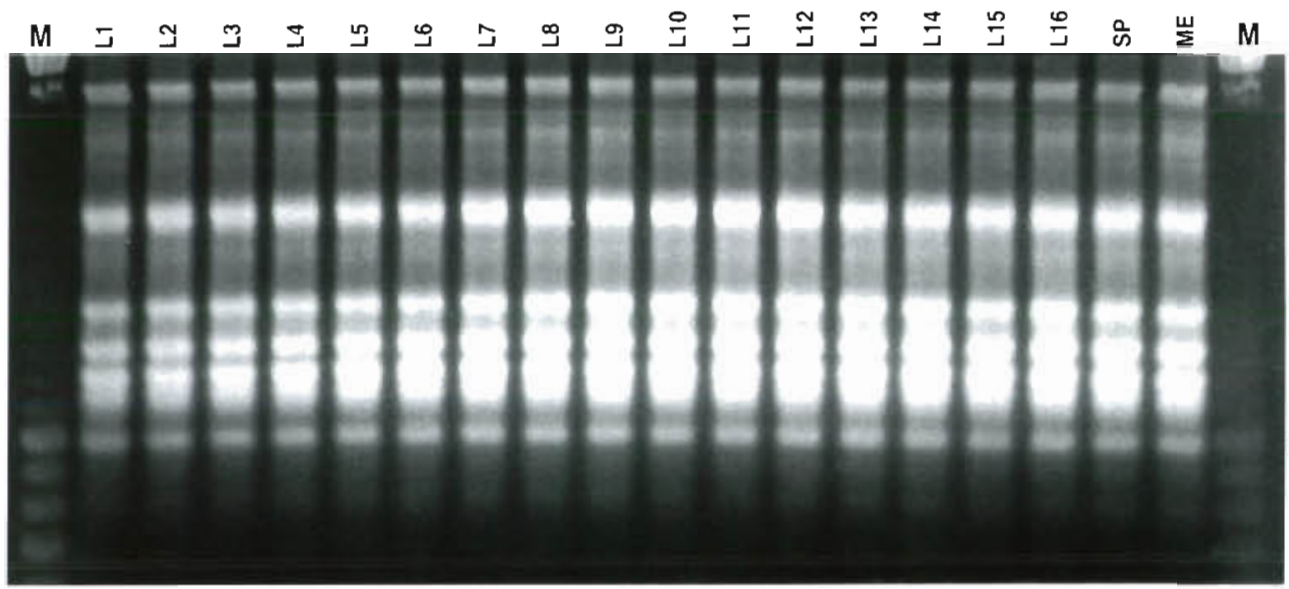

\section{$0.8 \mathrm{~kb}$}

Fig. 4. Representative RAPD-PCR banding patterns for the 18 individual plants of Posidonia oceanica from 3 populations. L1 to L16: Lacco Ameno; SP: San Pietro; ME: Medas Islands; $M$ : molecular size marker Upper panel: pnmer OPC-5; lower panel: OPC-7 The only polymorphic product is indicated with an arrow

\section{$0.8 \mathrm{~kb}$}


the mother plant and do not recruit inside the mother meadow. Further, it indicates that the morphotypes observed at the different depths here reflect only phenotypic characteristics, as found in other seagrass studies (Alberte et al. 1994).

Our findings highlight the unique capabilities of molecular approaches for assessing the role of sexual reproduction in clonal plants, like seagrasses, where seed dispersal is regulated by stochastic processes. The results presented here indicate that Posidonia oceanica, the basis of the littoral food webs in the Mediterranean Sea, possesses little genetic diversity in the Western Mediterranean basin, which has been subjected to increasing anthropogenic stress, implicated in meadow regression (Bellan-Santini et al. 1994). Certainly, low genetic diversity, together with the low rhizome elongation rate, may significantly affect the ability of $P$. oceanica populations to respond to direct and indirect impacts of environmental climate change. The fact that $P$. oceanica represents a final stage of succession comparable to some terrestrial systems, such as oak forests (Pianka 1983, Huston \& Smith 1987. Mazzella et al. 1993), has to be taken into account. In fact, if on the one hand such species form the structure of ecosystems, where the associated algal and animal communities are characterized by high species richness and diversity (Gambi et al. 1992, Mazzella et al. 1992), on the other hand they are also characterised by a low resilience to disturbance. Recently, Tilman \& Downing (1994) showed that increased 'structural' species richness in grasslands increased the resilience and stability of the system to environmental perturbation. As such, this study supports the notion that greater species diversity increases stability (Pimm 1984) in systems characterised by more structural species. Since it is reasonable to hypothesize that greater genetic variability of a single species should be related to enhanced stability of that species, the stability of 'structural-mono-specific' systems should be ensured by the level of genetic diversity of the populations. Therefore, it is possible that the low genetic diversity within and between populations of $P$. oceanica is contributing to the increasing losses in abundance of this key species in the Western Mediterranean basin.

\section{LITERATURE CITED}

Alberte RS, Suba GK, Procaccini G, Zimmerman RC, Fain SR (1994) Assessment of genetic diversity of seagrass populations using DNA fingerprinting: implications for population stability and management. Proc Natl Acad Sci USA 91:1049-1053

Avise JC (1994) Molecular markers, natural history and evolution. Chapman \& Hall, New York

Baker SS, MacCarthy M, Smith PJ, Perry AP, Chambers GK
(1992) DNA fingerprints on orange roughy, Hoplostethus atlanticus: a population comparison. Mar Biol 113: $561-567$

Bellan-Santini D, Lacaze JC, Poizet C (1994) Les biocénoses marines et littorales de Méditerranèe, synthèse, menaces et perspectives. Musèm National d'Histoire Naturelle, Paris

Boudouresque CF, Jeudy de Grissac A (1983) L'herbier à Posidonia oceanica en Méditerranée: les interactions entre la plante et la sédiment. J Rech Océanogr 8 (2-3):99-122

Boudouresque CF, Jeudy de Grissac A, Olivier J (eds) (1984) First International Workshop on Posidonia oceanica Beds. GIS Posidonie, Marseille

Boudouresque CF, Thelin I (1985) Floraison et fructification de Posidonia oceanica: un protocole d'étude standardisé. Rapp Comm Int Mer Médit 29 (5):177-179

Buia MC, Mazzella L (1991) Reproductive phenology of the Mediterranean seagrasses Posidonia oceanica (L.) Delile, Cymodocea nodosa (Ucria) Aschers., and Zostera noltii Hornem. Aquat Bot 40:343-362

Buia MC, Zupo V, Mazzella L (1992) Primary production and growth dynamics in Posidonia oceanica. PSZN I: Mar Ecol 13(1):2-16

Burke T, Hanotte O, Bruford MW, Cairns E (1991) Multilocus and single locus minisatellite analysis in population biological studies. In: Burke T, Dolf G, Jeffrey AJ, Wolff R (eds) DNA fingerprinting: approaches and applications. Birkhauser, Berlin, p 154-168

Carvalho GR, Maclean N, Wratten SD, Carter RE (1991) Differentiation of aphid clones using DNA fingerprints from individual aphids. Proc R Soc Lond B 243:109-114

Caye G, Meinesz A (1984) Observations sur la floraison et la fructification de Posidonia oceanica dans la Baie de Villefranche et en Corse du Sud. In: Boudouresque CF, Jeudy de Grissac A, Olivier J (eds) International Workshop on Posidonia oceanica Beds, Vol 1. GIS Posidonie, Marseille, p $193-201$

Caye G, Meinesz A (1992) Analyse des modalités de la multiplication végétative et de la reproduction sexuée de Posidonia oceanica et de ses conséquences sur la constitution génétique des herbiers. Rapp Comm Int Mer Médit 33:32

Coffroth MA, Lasker HR, Diamond ME, Bruenn JA, Bermingham $E$ (1992) DNA fingerprints of a gorgonian coral: a method for detecting clonal structure in a vegetative species. Mar Biol 114:317-325

Coyer JA, Robertson DL, Alberte RS (1994) Genetic variability within a population and between diploid/haploid tissue of Macrocystis pyrifera (Phaeophyceae). J Phycol 30: $545-552$

Coyer JA, Steller DL, Alberte RS (1995) A field-compatible method for extraction of fingerprint-quality DNA from Macrocystis pyrifera (Phaeophyceae). J Phycol 31: $177-180$

Doyle JJ, Doyle, JL (1987) A rapid DNA jsolation procedure for small quantities of fresh leaf tissue. Phytochem Bull 19:11-15

Franconi R, Barcaccia G, Paglialonga A, Micheli C (1995) Investigation of genomic polymorphism in Posidonia oceanica plants collected in different areas of Mediterranean Sea using RAPD markers. Rapp Comm Int Mer Médit 34:29

Gambi MC, Lorenti M, Russo GF, Scipione MB, Zupo V (1992) Depth and seasonal distribution of some groups of the vagile fauna of the Posidonia oceanica leaf stratum: structural and trophic analyses. PSZN I: Mar Ecol 13(1):17-39

Gustafsson L, Gustafsson P (1994) Low genetic variation in Swedish populations of the rare species Vicia pisiformis 
(Fabaceae) revealed with rflp (rDNA) and RAPD. Plant Syst Evol 189:133-148

Hadrys H, Balik M, Schierwater B (1992) Applications of random amplified polymorphic DNA (RAPD) in molecular ecology. Mol Ecol 1:55-63

Huston M. Smith T (1987) Plant succession: life history and competition. Am Nat 130 (2):168-1.98

Jeffreys AJ, Wilson V, Thein SI (1985) Hypervanable 'minisatellite' regions in human DNA. Nature 314:67-73

Kirby LT (1990) DNA fingerprinting, an introduction. Stockton Press, New York

Larkum AWD, McComb AJ, Shepherd SA (1989) Biology of seagrasses. Elsevier, Amsterdam

Lynch $M$ (1990) The similarty index and DNA fingerprinting Mol Biol Evol 7 (5):478-484

Mateo MA, Romero J, Pérez M, Littler M, Littler D (in press) Dynamics of millenary organic deposits resulting from the growth of the Mediterranean seagrass Posidonia oceanica Estuar Coast Shelf Sci

Mazzella L, Buia MC (1989) Variazıoni a lungo termine in alcuni parametri strutturali di una pratena a Posidonia oceanica. Nova Thalassia 10 (suppl 1):533-542

Mazzella L, Buia MC, Gambı MC, Lorentı M, Russo GF, Scipione MB, Zupo V (1992) Plant-animal trophic relationships in the Posidonia oceanica ecosystems of the Mediterranean Sea: a review. In: John DM. Hawkins SJ, Pnce JH (eds) Plant-animal interaction in the marine benthos Clarendon Press, Oxford, p 165-187

Mazzella L, Gambi MC, Russo GF, Buia MC (1984) Deep flowering and fruiting of Posidonia oceanica beds around the Island of Ischia (Gulf of Naples, Italy). In: Boudouresque CF, Jeudy de Grissac A. Olivier J (eds) International Workshop on Posıdonia oceanica Beds, Vol 1 GIS Posidonie, Marseille, p 203-209

Mazzella L, Scipione MB, Gambi MC, Buia MC, Lorenti $M$, Zupo V, Cancemi G (1993) The Mediterranean seagrasses Posidonia oceanica and Cymodocea nodosa. A comparative overview. In: Ozhan E (ed) First International Conference on the Mediterranean Coastal Environment, Vol 1. Med Coast, Antalya, p 103-116

McRoy CP, Helfferich C (1977) Seagrass ecosystems. A scientıfic perspective $M$. Dekker, New York

Meinesz A, Caye $G$, Loquès F, Molenaar H (1993) Polymor-

This article was submitted to the editor phism and development of Posidonia oceanica transplanted from different parts of the Mediterranean into the National Park of Port-Cros. Bot Mar 36:209-216

Nybom H, Schaal BA (1990) DNA fingerprints' reveal genotypic distributions in natural populations of blackberries and raspberries (Rubus, Rosaceae). Am J Bot 77:883-888

Pianka ER (1983) Evolutionary ecology, 3rd edn. Harper \& Row, New York

Pimm SL (1984) The complexity and stability of ecosystesms. Nature 307:321-326

Procaccini G, Mazzella L (1996) Genetic variability and reproduction in two Mediterranean seagrasses. In: Kuo J, Phillips RC, Walker DI, Kirkman $\mathrm{H}$ (eds) Seagrass biology: Proceedıngs of an International Workshop. Rottnest Island, Western Australia, 25-29 January 1996. University of Western Australia, Nedjands, p 85-92

Rafalski JA, Tingey SV (1993) Genetic diagnostics in plant breeding: RAPDs, microsatellites and machines. TIG (Trends Genet) $9(8): 275-280$

Russell JR, Hosein F, Johnson E, Waugh R, Powell W (1993) Genetic differentiation of cocoa (Theobroma cacao L.) populations revealed by RAPD analysis. Mol Ecol 2:89-97

Thelm l, Boudouresque CF (1985) Posidonla oceanica tlowering and fruiting: recent data from an international inquiry. Posidonia News 1 (1):5-14

Tilman D, Downing JA (1994) Biodiversity and stability in grasslands. Nature 367:363-365

Van Oppen MJH, Diekmann OE, Wiencke C, Stam WT, Olsen JL (1994) Tracking dispersal routes: phylogeography of the Arctic-Antarctic disjunct sea weed Acrosiphonia arcta (Chlorophyta). J Phycol 30:67-80

Van Oppen MJH, Olsen JL, StamWT (1995) Genetic variation within and among North Atlantic and Baltic populations of the benthic alga Phycodrys rubens (Rhodophyta). Eur J Phycol 30:251-260

van Pijlen IA, Amos B, Dover GA (1991) Multilocus DNA fingerprinting applied to population studies of the minke whale Balaenoptera acutorostrata. In: Hoelzel AR (ed) Genetic ecology of whales and dolphins. International Whaling Commission, Cambridge, p 245-254

Waycott M (1995) Assessment of genetic variation and clonality in the seagrass Posidonia australis using RAPD and allozyme analysis. Mar Ecol Prog Ser 116:289-295

Manuscript first received: December 22, 1995

Revised version accepted: March 22, 1996 